\title{
ACADEMIC BACKGROUND AS AN INFLUENCING FACTOR IN THE GEN Y'S SUSTAINABLE CONSUMPTION HABITS
}

\author{
J.P. Bernardes ${ }^{1}$, A.D. Marques ${ }^{1}$, F. Ferreira ${ }^{1}$, M. Nogueira ${ }^{2}$ \\ ${ }^{1}$ University of Minho, 2C2T, Textile Department, Guimarães (PORTUGAL) \\ 2 IPAM, IPAM Lab, Porto (PORTUGAL)
}

\begin{abstract}
The main goal of this paper is to understand if a different academic background can have an influence in the Millennials' perceptions regarding sustainability and their 'green' consumption habits of footwear in Portugal. The research method will be through the analysis of two focus groups, one with marketing students and other with fashion students. The analysis of the focus groups allows a better understanding between the gap of what Millennials think about sustainability and how they perceive it, with their actual consumption habits regarding footwear. In order to design a solid focus group, some influencing factors were selected from the literature review and will be further subject of analysis: Consumption habit; Economic availability; Physical availability; Personal benefits; Consumer consciousness and Personal perceived importance.
\end{abstract}

Keywords: Sustainability, Millennial Generation, Consumer Behaviour, Footwear Industry, Academic Background.

\section{INTRODUCTION}

These days, the survival of the human being is not so much a matter of how many we are, but how much space that each of us takes up on planet Earth, how does it become necessary to produce to satisfy the individual consumption, the amount that each one of us consumes energy, or, the waste produced by each person in a certain space of time. All the factors mentioned above form the ecological footprint [1]. It is necessary to use the natural resources of our planet with enough awareness, so that future generations are not affected by the current lack of sustainable planning [2]. Based on the desire of preserving the environment without sacrificing economic growth and social development, the concept of sustainable development arises. This is a concept that has evolved to a sustainability perspective and brings together three vital aspects: environmental, economic and social pillars [3].

Associated to a sustainable development is the concept of sustainable product. This concept can be misleading because the impacts that any product has on social and ecological environment depends not only of its production, but also of its use by consumers [4]. A successful sustainable design is created for and about customers as people and not just as consumers. So, the design has a healthy result for the whole supply chain and for the ecosystem [5]. A supply chain is defined as "a set of three or more entities (organizations or individuals) directly involved in the upstream and downstream flows of products, services, finances, and/or information from a source to a customer." [6]. One of the main goals of a supply chain is meeting the end consumer demand [7]. Sustainable supply chains must ensure that their products and services are sustainable not only in the upstream of the chain but also in the downstream to consumers for it to be a proper sustainable product or service [8]. However not all companies seem to be open to be 'green', due to sustainability practices increasing their operation costs [9]. The efforts for being sustainable result in the increase of costs and therefore companies tend to put higher prices in their products or services [10]. Even though consumers are willing to buy 'green', they are not willing to incur in extra costs, as this paper will show further on.

It is important to understand consumers and what influences them because they are an important part of the fashion system and can create a valuable influence in the pursuit of sustainability in the fashion industry. Encouraged by low prices and influenced by marketing campaigns and trend changes, consumers tend to speed their fashion consumption [11]. The younger consumers, called the generation Y (Millennials), are defined as a group of people born between 1980 and 2000 [12] and maintain a positive attitude in relation to sustainability in general. However, there is a clear contradiction between how Millennials think about sustainability and what they do when it comes to a sustainable consumption [13]. 


\section{STATE OF ART}

\subsection{Influencing factors in the Millennials purchasing habits}

Since only studying the 'green' attitudes of Millennials will not produce conclusive results on the behaviour of young consumers to buy sustainable products, it is interesting to determine what factors can influence the attitude-behaviour relationship. Several studies suggest that there is a difference of attitude of 'green' purchasing behaviour due to the complex nature of personal and situational influences [14]. Personal factors are internal influences. The attitude is a personal factor important in the purchase of sustainable products but doesn't explain why the young consumers don't buy this type of products. Other examples of personal factors are awareness, trust, priorities, emotion and control (to the extent that a consumer believes to have control over the events that affect) [14]. The awareness factor, for example, is defined as the amount of time that was spent in the processing of information about 'green' and sustainable products [15] and the academic background plays an important role in this personal factor. Situational influences are the external influences that a person cannot control, but which affect the relation attitude-behaviour. Examples of situational factors: time, opportunity, money or the ability to perform the desired behaviour [16].

Millennials' purchasing power is rising and will be at its peak between the period of 2020 and 2050, [17]. The methodology adopted in this paper is qualitative through the use of two focus group, all participants still with no established purchasing power, but they will be the adult consumers of the next 30 years. So, for companies its necessary to understand them now, in order to know how to establish lasting connections in the near future.

In order to understand Millennials, some influencing factors were selected and will be further subject of analysis throughout this paper, and they are:

\subsubsection{Consumption habits}

Habits are behavioural routines that are repeated regularly and tend to develop subconsciously. A habit is a fixed form of thinking, acting or feeling and is determined by the repetition of a prior experience. When a behaviour is often performed, can conduct an immediate behaviour under the control of a usual process [18].

\subsubsection{Economic availability}

The author [19] perceives a relationship between income and ecological footprint. Consumers with higher incomes have a negative footprint, while consumers with lower income have a positive footprint. The price of 'green' products depending on the economic availability is the most common barrier for consumers not buying 'green' products or services [20]. However, the amount of expendable money also seems to be a personal factor since it is related to the willingness to pay a certain price. Some studies claim that the income does not affect the behaviour of buying 'green' [2122]. The author [23] hopes that this personal factor overlaps the contextual factor of economic availability in the decision-making process.

\subsubsection{Physical availability}

The physical availability of 'green' products in relation to the time that a consumer has or is willing to spend on shopping, influences the amount of 'green' purchases 'made. Physical availability is related to the ease or difficulty of obtaining or consume a certain product [24]. Consumers want to find sustainable products in regular stores, alongside conventional products [25-26].

\subsubsection{Personal Benefits}

Personal benefits, personal concern or personal interest, all refer to the efforts that a person has to do to satisfy their needs and desires. Consumers will assess whether the expected behaviour (for example, what to do) corresponds with their own personal concerns [27]. There is the tendency to decide in favor of their own interests, which is thus related to the fact that consumers often fail to estimate the actual impact of buying 'green' in their lives [28]. A consumer will buy a 'green' product, when in addition to the environmental benefit, they realize some benefit individual direct in acquiring the product [29]. 


\subsubsection{Consumer Consciousness}

This factor is defined as the amount of time that was spent in the processing of information about 'green' and sustainable products [30]. It is important that consumers are aware of the fact that buying 'green' can be a criterion of purchase and should also pay attention to the communication of organizations about products of this type [31]. Consciousness holds a key role in the acquisition of sustainable products and is a bonus when making a 'green' purchase. When consumers are not aware of the existence of these types of products, they will never be able to form strong attitudes and intentions regarding the purchase of sustainable products. So, the level of consciousness influences the relationship between 'green' attitudes and purchase intentions [32].

It is in this factor that the academic influences come in to play. Participants in both focus group were either marketing management or fashion design students as the study was intended to probe if the attitudes and behaviour of people that who are typically well-informed might have some influence on their purchasing habits. Different societies also have different beliefs and behaviours regarding sustainability principles, as well as different levels of knowledge. In the case of the fashion design students it is important to understand from the results of the discussion if they are aware of the impacts of unsustainable fashion supply chains and if they perceive the positive implications that a sustainable supply chain of a fashion brand can have on a sustainable development. Regarding marketing students, the intention was to evaluate students' perception of the ability of marketing to imbed sustainability as guiding principle in devising marketing strategies and tactics as well as ability to influence change in consumption patterns towards more sustainable life-style. Change is possible only if those who are responsible for the change believe they have adequate tool to make change happen [33]. Introducing environmental topics in a business schools' curriculum induces greater levels of environmental concerns among students [34]. But it necessary to be aware, as [35] argues, that addressing students' sensitivity to environmental issues does not necessarily lead to changes in behaviour "...the student might be sensitive, and even sympathetic, to the need for environmentally responsible management practices, but still may consider them peripheral, or even antithetical, to the success of the firm." Lecturers can also exert influence over their students' attitudes and behaviour; referring to critical pedagogy, [36] discussed how 'education and the classroom have the potential to change society at large for the better'. Additionally, environmental concern and environmentally friendly behaviours have been associated with environmentally aware and informed consumers [37].

\subsubsection{Personal perceived importance}

The personal perceived importance is a type of attitude that explains whether consumers consider sustainability issues important to them, or as a problem of society as a whole [38]. So, the selfinvolvement level with the environment determines the amount of 'green' purchases consumers do. Consumers can have a very positive attitude in relation to sustainability, but at the same time feel that the preservation of the environment isn't their responsibility. [38]

As will be explained in the next section of this paper (3. Methodology), this paper will analyze each of the influencing factors stated above through the focus group methodology, allowing a better understanding if the academic background of participants has influence on their 'green' purchasing habits regarding footwear in Portugal.

\section{METHODOLOGY}

The main goal of this paper is to study if the academic background plays an important role in influencing the Gen Y's sustainable consumption habits regarding footwear in Portugal. The research method will be through the analysis of two focus group, one with marketing management students (from IPAM - The Marketing School) and another with fashion design students (from University of Minho), all Millennials from Portugal. Both fields of marketing and fashion were selected to be compared and analyzed because both degrees study the consumer but marketing has a special focus on management and fashion a focus on the actual fashion value chain. Each focus group had nine Millennial participants (excluding the moderator and an observer). To be a part of this focus group there were some restrictions: being born between 1980 and 200; being active on digital platforms and having footwear purchasing habits. The moderator followed a discussion guide but allowed flexibility to consider any relevant topics that emerged. Care was taken to make participants feel comfortable and respected in a non-judgmental and friendly environment, which encouraged disclosure of participants' views [39]. The focus group lasted $1 \mathrm{~h} 30$. Audio and video recordings were made of the discussion, which were then transcribed and subjected to analysis. 
The analysis of the focus groups allows a better understanding between the gap of what Millennials think about sustainability and how they perceive it, with their actual consumption habits regarding footwear. In order to design a solid focus group, the following influencing factors were selected from the literature review and will be further subject of analysis: Consumption habit; Economic availability; Physical availability; Personal benefits; Consumer consciousness and Personal perceived importance.

\section{RESULTS AND DISCUSSION}

\subsection{Millennials perceptions on sustainability and 'green' products}

This first section of the discussion is focused in understanding Millennials' thoughts on sustainability and 'green' products in general. After these first three questions is the analysis and results to each of the influencing factors selected from the literature review. All of the questions below were asked in the focus groups and the answers are divided by focus group (Marketing students/Fashion students).

Who do you consider the main responsible for sustainability? How/Why?

Marketing students - "Us, the Human Being. Because we're the ones who use the resources and have the ability to manage them properly. At an industrial, economic and social level, the human being is always the main responsible."; They believe that companies also have a great responsibility regarding the environment and sustainability because factories pollute the air and water. Also, marketing students felt that Marketing plays a key role in sustainability because "the purchase behaviors are the reflection of the way society "educates" and tells us what we should consume, and brands can have a great impact on those decisions". They stated that the impacts of every purchase should be explained to consumers, so that they can make an informed and aware decision and know what the real repercussions of their actions are. "Brands should worry about educating consumers."

Fashion students - "We are all responsible. Both producers and consumers. If there's consumption, there's production, and if there's production there's consumption. It's a vicious cycle.", "Nowadays consumers prefer to spend $5 €$ on a piece of clothing rather than $40 €$, even if the quality is significantly lower. This is our mentality and it needs to change. Society has to be taught better".

What are your thoughts on 'green' products? Why?

Marketing students - The described 'green' products as with higher quality but also higher prices. And "because of these higher prices, we don't pay attention to them and opt for the easiest and more convenient choice". The financial aspect overweighs the long-term personal benefits from consuming 'green', so consumers only pay attention to the price tag and not the components or materials of the products.

Fashion students - "There is still a lot to develop in this sector, it is being explored very recently and there is a lot more to learn and do"; "Its consumption should be more encouraged, even in the media. Marketing wise we don't see a lot of communication efforts from 'green' brands so it is difficult to be present in the consumer's mind"; And also "sustainable products always makes us remember of nonappealing products. There is still a lot to explore in terms of design and production. There needs to be a reeducation of the consumer".

Do you know the term Fast Fashion? and Slow Fashion? How do you explain them? Any example?

Marketing students - Are not familiar with the terms.

Fashion students - Everyone is familiar with the terms. They defined fast fashion as "clothes that are produced in mass production cycles, with weekly trends". They believe these brands have a greater impact on the environment due to the constant use of materials to produce more and more. Every participant said Zara as the main example. Regarding slow fashion, every participant immediately said that it is fashion with less production, made with sustainable materials and that lasts a very long time due to the quality of the materials. Higher quality of materials means higher price, but it is worth it because its clothes that last a lot more. It's an investment. However, no one could name a brand as an example.

\subsection{Millennials' influencing factors in purchasing 'green' footwear}

The next section of the discussion is the analysis of each of the influencing factors regarding the consumption of 'green' footwear: 


\subsubsection{Consumption habits}

Do you have the habit of buying sustainable footwear? Why/Why Not?

Marketing students - Every participant responded negatively. They believe that footwear brands should offer a quality guarantee for their products, with the option of having maintenance and/or repair service due to the materials. It is not enough to ensure durability, it is necessary to explain and educate why certain models are more durable and therefore sustainable (processes, production and materials wise). They also state that there is a huge lack of communication between the brands and the consumers. They are not aware if footwear brands have or haven't got 'green' lines, and they believe this is the brand's fault and not only theirs.

Fashion students - Just like marketing students, Fashion students also responded negatively. They understand the impact that footwear production has on the environment and how a 'green' footwear line is beneficial for either for the consumer and producer, however, none has the habit of buying sustainable footwear. The main reason is the price being very high due to the materials used in production.

\section{Do you buy your footwear to a certain brand(s) out of habit? Why/Why Not?}

Both marketing and fashion students claimed to have a certain routine when buying footwear. They usually visit the same stores and buy the same brands because they already know that those brands have products that adds value to them.

\subsubsection{Economic availability}

Every participant, marketing and fashion, agreed and shared the same point of view that the economic aspect is the main barrier that prevent them from buying 'green'. They all believe that the price of 'green' footwear can be higher than regular footwear, but not as high as it is right now. Prices are very disparate, however slightly higher price seems fair to them because of the sustainable materials inherent in producing a 'green' shoe.

\section{Do you think 'green' footwear is worth the extra financial effort? Why/Why Not?}

All said yes, but only if the product has a higher quality, lasts longer and if the price is not much more than regular footwear. Marketing students added that nowadays sustainable footwear brands don't know how to reach to their audience. One of the students said "There must be a lot of footwear brands producing 'green' lines, but they aren't successful in reaching us. Their marketing efforts are not enough to make us know who they are, let alone make us see value in buying their products." Another student also said that "brands shouldn't go immediately into the market with a 'green' line without first justifying to the market why they are doing it. They must be able to create a need in the consumer so that he's able to see value in buying sustainable footwear". They all believed that there is still a lot of improvements to do concerning marketing and communication efforts, and that consumers need to be informed and educated by the brands in order to change how the market acts.

\subsubsection{Physical availability}

This factor also had unanimity, due to the fact that none of the participants could name a sustainable footwear brand, therefore don't know where they can find a 'green' line. However, there is a clear difference between marketing and fashion students when it comes to identifying sustainable footwear. Only fashion students claimed to know how to read labels and detect the different materials in producing footwear. Even though they have the skills to read labels and understand materials and its impacts, the only reason they look at the label is to see how the maintenance of the product should be done.

\subsubsection{Personal benefits}

What are the personal benefits you believe there are in consuming 'green' footwear? Why?

Marketing students - Two important statements, shared by two participants but with general agreement by everyone were: "Health. No only ours but everyone else's, because in consuming 'green' we are reducing our ecological footprint thus helping the planet"; "Space for all. Because the less we consume, the less its produced to satisfy the individual consumption. And with less production, the less waste and less space we take in our planet". 
Fashion students - "It is beneficial for our health and state of mind because we are doing the right thing for us and for everyone around us".

It is interesting to observe that every participant acknowledged that being 'green' is extremely beneficial not only for them but for society as a whole even though they don't have 'green' purchasing habits regarding footwear. Discussing with them was possible to note that the extra financial effort that is inherent in buying sustainable footwear doesn't justify the personal benefits of being 'green'. Millennials want to be 'green', but they can't afford to be 'green'. They also felt that, even though they don't buy 'green', they can be 'green' if they consume in a smart way. One of the participants said that "We don't need to have all our pairs of shoes made with sustainable materials, but if we take care of them and make them last longer we are helping the environment. Maintenance is key in achieving a more sustainable lifestyle too. It's all about balance".

Would you be willing to buy shoes made of sustainable materials? Why/Why Not?

Every participant responded positively, only if the design and price aspects are in line with their preferences and budget limitations.

\subsubsection{Consumer consciousness}

When asked "what you think when you hear the expression "sustainable footwear"?" the marketing students responded "Sustainable materials", "No animal testing", "Hand-made" and the fashion students answered "Materials that last longer", "Unappealing designs", "Old-fashioned".

Both groups mentioned the materials therefore are aware that sustainable footwear is made with alternative materials in order to not impoverish the natural resources of the planet. In this question, the discussion went in to two very different paths because fashion students showed higher sensitivity to the design aspect of a 'green' shoe, claiming that these are not current and don't appeal to Millennials at all. And marketing students stated that sustainable footwear brands are 'ghosts' because none of them actually knows one.

They also believe that if they knew the actual impacts that consuming a 'green' product in detriment of a regular one would have in their lives and the world, that they would be able to make a more informed decision and that would highly influence their purchasing decision. One of the marketing students even said that "We are not being educated properly. We are not aware of the impacts of our decisions and that needs to change. We need to be educated now so we can still act in time, and that's the companies fault." And also that "We have to pay more attention to the companies' efforts of companies and check if what they say they do is actually true. We are responsible but we are not alone. We need to be educated in order to change our consumption habits."

When it comes to producing footwear, what are the materials you think are the most eco-friendly? And the least? Why?

Both groups showed some difficulty in answering different sustainable materials, having only "cork" "cotton" and "synthetic leather" as answers. They all answered "leather" as the least sustainable material. Even though they couldn't name more than a few alternative materials, they shared a strong point of view regarding the use of materials. They believe that, for example, if an animal is used $100 \%$, with no waste left behind, that is being sustainable in a way.

Before buying footwear, do you try to see if it's made with sustainable materials? Why/Why Not?

None of the participants answered positively. Only the fashion students said that they try to see if the materials in the shoes they are buying have higher durability and not if they are actually sustainable.

\subsubsection{Personal perceived importance}

How important is eco-friendly footwear to you and to the pursuit of sustainability?

Marketing students - "The word 'friendly' says it all. These types of products improve not only our quality of life but also the planet in general." They stated that by producing less and with more quality, there's less waste and therefore less impact on the planet. One of the participants added that "We are aware that we should consume 'green', but to do so we need to have 'green' products that appeal to us. We won't buy something we don't like just because of sustainability. It has to be a win-win situation".

Fashion students - "We tend to wear the same pair of shoes for a long time, so if it's eco-friendly it becomes an investment because it has higher durability and less impact on the environment." In the 
lines of the marketing students, fashion participants also felt that "there is little options regarding sustainable fashion, and the one that exists doesn't appeal to us"; "Although we are aware of the impacts, we want to be trendy and in fashion. We don't want to have to reduce our choices only to sustainable fashion because there is very little to choose from". Another student even said that "If I had two identical shoes in front of me, one being sustainable and the other one not, with identical prices, I would opt for the sustainable model without a doubt".

\section{CONCLUSIONS}

After selecting and analyzing the influencing factors that can have a positive or negatively impact the gap between Millennials' attitude and behaviour concerning sustainability and sustainable fashion, some interesting conclusions are now possible to obtain. Although fashion students have a better understanding of design and aesthetics and marketing students of business and communication, both groups shared a similar point of view regarding the consumption of sustainable footwear. Both marketing and fashion students are fully aware of their role in society and therefore know that they should consume 'green' and that by doing so they are contributing positively to the environment and improving their lives as well. All agreed that being 'green' adds value to their life and that is extremely beneficial not only for them but to society in general. They are aware that 'green' products have higher quality and therefore higher prices. It is possible to conclude that price prevents them from buying 'green', but that isn't the only barrier. They stated that design and aesthetics play a major role in their decision making and they associate 'green' to old-fashioned and unappealing products. They also said that they have very limited design choices and that (alongside the higher price) keeps them from buying sustainable fashion.

When it comes to consumption habits, Millennials don't have the habit of buying 'green' footwear. That happens because no one actually knows a brand with sustainable footwear. They feel that it is the brands' job to reach Millennials and to influence their purchasing decisions by informing and educating them of the impacts that being 'green' can have in the planet. For both groups, the economic availability to purchase 'green' products presented a strong negative influence on the 'green' purchasing behaviour and was mentioned as the main barrier. One of the solutions for Millennials would be a decrease in the price, even if it's a little above the regular products. They are willing to incur in a small extra effort. Also, the availability of products showed to very important in predicting 'green' purchases because they can't find 'green' products alongside regular ones, and the ones they find they don't think that appeals to them.

Although both groups have very different backgrounds both groups believe that the key to change is education. In general, every participant blamed not only themselves for not consuming 'green' but also blamed how 'green' is being communicated and marketed. They feel that 'green' brands don't know how to please Millennials, that they haven't heard of them so "brands must be doing something wrong too. We are not the only ones to blame." They all understand the potential that marketing can have in influencing Millennials' consumption patterns and decisions, but "it needs to be done the right way" claimed one of the marketing students.

The main limitation of this study is that the results from the analyzed sample are $100 \%$ Portuguese, therefore it is not possible to extrapolate these results to other countries. Even though it is the same generation worldwide, each culture has its own impacts on the Millennials education, and therefore, consumption habits.

As future research it would be very interesting to add 'Marketing Efforts' as an influencing factor by analyzing the marketing strategies done by sustainable footwear brands and how they engage with the Millennial generation. Also, it would be interesting to study different ways to increase consumer awareness in what comes to buying 'green', having the 'Marketing Efforts' factor as the starting point.

\section{ACKNOWLEDGEMENTS}

"This work is financed by FEDER funds through the Competitivity Factors Operational Programme COMPETE and by national funds through FCT - Foundation for Science and Technology within the scope of the project POCI-01-0145-FEDER-007136". 


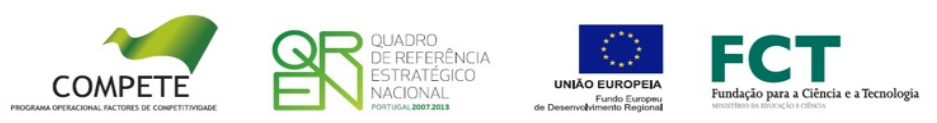

\section{REFERENCES}

[1] Kiperstok, A. 2005. Sustentabilidade ambiental: produção e consumo; I congresso internacional de cooperação universidade-indústria.

[2] Canciglieri, JR., O.; Cardoso, R.; Pereira, S. 2011. Uma Visão Tecnológica sobre o Desenvolvimento de Produtos e a Sustentabilidade. Congresso Brasileiro de Gestão de Desenvolvimento de Produto, Porto Alegre.

[3] Brundtland, G. H. 1991. Nosso Futuro Comum. Rio de Janeiro, Editora de Fundação Getúlio Vargas.

[4] Stegall, N.,2006, Designing for Sustainability: A Philosophy for Ecologically Intentional Design. Design issues, 22, p 96. Shedroff, N. and Lovins, L. H., 2009, Design is the problem: the future of design must be sustainable, Brooklyn, N.Y., Rosenfeld Media.

[5] Shedroff, N. and Lovins, L. H. 2009. Design is the problem: the future of design must be sustainable, Brooklyn, N.Y., Rosenfeld Media.

[6] Mentzer, J., DeWitt, W., Keebler, J. S., Nix, N. W., \& Smith, C. D. (2001). Journal of Business Logistics. Vol 22. No. 2.

[7] Bowersox, D. J., Closs, D. J., and Stank, T. P. (2000). Ten Mega-Trends That Will Revolutionize Supply Chain Logistics. Journal of Business Logistics, 21(2), 1-15.

[8] Morali, O., and Searcy, C. (2013). A Review of Sustainable Supply Chain Management Practices in Canada. Journal of Business Ethics, 117(3), 635-658.

[9] Devinney, T. M. (2009). Is the Socially Responsible Corporation a Myth? The Good, the Bad, and the Ugly of Corporate Social Responsibility. Academy of Management Perspectives , 4456.

[10] Husted, B. W., Russo, M. V., Meza, C. E. B., and Tilleman, S. G. (2013). An exploratory study of environmental attitudes and the willingness to pay for environmental certification in Mexico. Journal of Business Research.

[11] Birtwistle, G. and Moore, C.M. 2006. Fashion adoption in the UK: a replication study. Paper presented at the Anzmac Conference, Brisbane, CA.

[12] Zemke, R. 2001. Here come the Millennials. Training Magazine, 38(7), 44-49.

[13] Cui, Y., Trent, E., Sullivan, P., \& Matiru, G. 2003. Cause-related marketing: How Generation Y responds. International Journal of Retail \& Distribution Management, 31(6), 310-320.

[14] Csutora, M. 2012. One more awareness gap? The behaviour-impact gap problem. Journal of consumer policy, p 1- 19.

[15] Baker, W., Hutchinson, J. W., Moore, D., and Nedungadi, P. 1986. Brand familiarity and advertising: Effects on the evoked set and brand preference. Advances in Consumer Research, 13(1), p 637-642.

[16] Ajzen, I. 2012. The theory of planned behavior. In P. A. M. Lange, A. W. Kruglanski and E. T. Higgins (Eds.), Handbook of theories of social psychology, 1, p 438-459. London, UK: Sage.

[17] Forbes. 2014a. The 10 social and tech trends that could shape the next decade. Available at: http://www.forbes.com/sites/sarwantsingh/2014/05/12/the- top-10-mega-trends-of-thedecade/2/\#47cbd7e55eae [Accessed: 25 February 2016].

[18] Ajzen, I., Czasch, C. and Flood, M. G., 2009, From Intentions to Behavior: Implementation Intention, Commitment, and Conscientiousness. Journal of Applied Social Psychology, 39(6), p 1356-1372.

[19] Csutora, M., 2012, One more awareness gap? The behaviour-impact gap problem. Journal of consumer policy, p $1-19$. 
[20] Bray, J., Johns, N., and Kilburn, D., 2011, An exploratory study into the factors impeding ethical consumption. Journal of Business Ethics, 98(4), p 597-608.

[21] Tanner, C., and Kast, S., 2003, Promoting sustainable consumption: Determinants of green purchases by Swiss consumers. Psychology \& Marketing 20, p 883-902.

[22] Rahim, R., Waheeda, J., and Tajuddin, K., 2011, The importance of corporate social responsibility on consumer behaviour in Malaysia. Asian Academy of Management Journal, 16(1), p 119-139.

[23] Bhattacharya, C. B., and Sen, S., 2004, Doing better at doing good: When, why, and how consumers respond to corporate social initiatives. California Management Review, 47(1), p 924.

[24] Vermeir, I., \& Verbeke, W. (2006). Sustainable food consumption: Exploring the consumer "attitude-behavioral intention" gap. Journal of Agricultural and Environmental Ethics, 19(2), 169194.

[25] De Pelsmacker, P., Janssens, W., Sterckx, E., and Mielants, C. (2005). Consumer preferences for the marketing of ethically labeled coffee. International Marketing Review 22, 512-30.

[26] Grimmer, M., and Wooley, M. (2012). Green marketing messages and consumers' purchase intentions: Promoting personal versus environmental benefits. Journal of Marketing Communications, 1-20. doi:10.1080/13527266.2012.684065

[27] Davis, I., 2012, How (not) to market socially responsible products: A critical research evaluation. Journal of Marketing Communications, p 1-15. doi: 10.1080/13527266.2012.696076

[28] Rokka, J., and Uusitalo, J., 2008, Preference for green packaging in consumer product choices - do consumers care ?, International Journal of Consumer Studies, 32, p 516-25.

[29] Nottage, A., 2008, The green agenda gets personal. Marketing, July, p 33-5.

[30] Baker, W., Hutchinson, J. W., Moore, D., and Nedungadi, P., 1986, Brand familiarity and advertising: Effects on the evoked set and brand preference. Advances in Consumer Research, 13(1), p 637-642.

[31] Jones, S., and Eden, C.,1981, OR in the community. Journal of the Operational Research Society, p 335-345.

[32] Silva, C. and Souza, T. M., 2012, Desenvolvimento de Sistema para Dimensionamento do Aquecedor Solar Popular de Água - Revista Sodebras, 7 (3), January.

[33] D. Pantelic, M. Sakal and A. Zehetner, Marketing and sustainability from the perspective of future decision makers. S.Afr.Journal Business Management, 2016, 47(1)

[34] Cordano, M., Ellis, K.M., \& Scherer, RF. 2003a. 'Natural capitalist: increasing business students' environmental sensitivity', Journal of Management Education, 27(2): 144-157.

[35] Thomas, T.E. 2005. 'Are business students buying it? A theoretical framework for measuring attitudes toward the legitimacy of environmental sustainability', Business Strategy \& the Environment, 14(3): 186-197.

[36] Catterall, M., Maclaran, P. \& Stevens, L. (1999) Critical marketing in the classroom: possibilities and challenges. Marketing Intelligence \& Planning, 17, 344-353.

[37] Brown, J. \& Wahlers, R. (1998) The environmentally concerned con- sumer: an exploratory study. Journal of Marketing Theory and Practice, 6, 39-47.

[38] Laroche, M., Bergeron, J., \& Barbaro-Forleo, G. (2001). Targeting consumers who are willing to pay more for environmentally friendly products. Journal of consumer marketing, 18(6), 503-520.

[39] Krueger, R. \& Casey, M. (2009) Focus Groups - A Practical Guide for Applied Research, 4th edn. SAGE Publications, Thousand Oaks, CA. Levy, S. (1959) Symbols for sale. Harvard Business Review, 37, 117- 124. 